\title{
Response of mountain meadows to grazing by recreational pack stock
}

\author{
DAVID N. COLE, JAN W. VAN WAGTENDONK, MITCHEL P. MCCLARAN, PEGGY E. MOORE, AND NEIL K. \\ MCDOUGALD
}

Authors are Research Biologist, Aldo Leopold Wilderness Research Institute, Rocky Mountain Research Station, Forest Service, Missoula, Mont. 59807; research forester, Yosemite Field Station, Western Ecological Research Center, U.S. Geological Survey, El Portal, Calif. 95318; Professor, School of Renewable Natural Resources, University of Arizona, Tucson, Ariz. 85721; Ecologist, Yosemite Field Station, Western Ecological Research Center, U.S. Geological Survey, El Portal, Calif. 95318; and Natural Resources Regional Advisor, University of California Cooperative Extension, Madera, Calif. 93637.

\section{Abstract}

Effects of recreational pack stock grazing on mountain meadows in Yosemite National Park were assessed in a 5-year study. Yosemite is a designated wilderness, to be managed such that its natural conditions are preserved. Studies were conducted in 3 characteristic meadow types: shorthair sedge (Carex filifolia Nutt.), Brewer's reed grass (Calamagrostis breweri Thurber), and tufted hairgrass [Deschampsia cespitosa (L.) Beauv.]. Horses and mules grazed experimental plots at intensities of 15 to $69 \%$ utilization for $\mathbf{4}$ seasons. In all $\mathbf{3}$ meadows, grazing caused decreases in productivity. The mean reduction after 4 years of grazing was $18 \%$ in the shorthair sedge meadow, $17 \%$ in the Brewer's reed grass meadow, and $22 \%$ in the tufted hairgrass meadow. Grazing also caused shifts in basal groundcover (usually a reduction in vegetation cover and increase in bare soil cover), and changes in species composition. Productivity and vegetation cover decreased as percent utilization increased, while bare soil cover increased as utilization increased. Changes in species composition were less predictably related to differences in grazing intensity. Passive management of grazing is insufficient in wilderness areas that are regularly used by groups with recreational stock. Wilderness managers need to monitor meadow conditions and the grazing intensities that occur. Our study suggests that biomass and ground cover are more sensitive indicators of grazing impact than species composition. Managers must make decisions about maximum acceptable levels of grazing impact and then develop guidelines for maximum use levels, based on data such as ours that relates grazing intensity to meadow response.

Key Words: horses, meadow productivity, mules, utilization, wilderness

About $17 \%$ of the federally owned lands available for public use have been designated as wilderness, to be managed such that their "natural conditions" are preserved (Wilderness Act, Public Law 88-577). A disproportionately large number of wilderness areas are located in the mountainous western United States,

Research was funded in part by the Yosemite Fund. Authors wish to acknowledge the help of numerous field assistants, capably coordinated by Wendy Stevens, pack stock support provided by the stables and ranger staff at Yosemite National Park, and help with data analysis from Neal Christensen, Kathy Gray, and David Turner.

Manuscript accepted 13 Jun. 03

\section{Resumen}

En un estudio de 5 años se evaluaron los efectos del apacentamiento de animales para actividades recreativas sobre las praderas de las montañas del Parque Nacional Yosemite. Yosemite esta designado como una área protegida virgen para ser manejada de tal manera que sus condiciones naturales sean preservadas. Los estudios se condujeron en 3 tipos característicos de pradera: "Shorthair sedge" (Carex filifolia Nutt.), "Brewer's reed grass" (Calamagrostis breweri Thurber), y "Tufted hairgrass" [Deschampsia cespitosa (L.) Beauv.]. Caballos y mulas apacentaron las parcelas experimentales a intensidades de 15 a $69 \%$ de utilización durante 4 estaciones. En los 3 tipos de praderas el apacentamiento causo una disminución en la productividad. Después de 4 años de apacentamiento, la reducción promedio fue $18 \%$ en la pradera de "Shorthair sedge" Nutt.) $17 \%$ en la de "Brewer's reed grass" y $22 \%$ en la de "Tufted hairgrass" [Deschampsia cespitosa (L.) Beauv.]. El apacentamiento también causó cambios en la cobertura basal (usualmente una reducción en la cobertura de la vegetación y un incremento en la cobertura de suelo desnudo) y cambios en la composición de especies. Conforme el porcentaje de utilización aumentó la productividad y la cobertura de plantas se redujo y el suelo desnudo aumentó. Los cambios en la composición de especies fueron menos predecibles en relación a las diferencias en la intensidad de apacentamiento. El manejo pasivo del apacentamiento es insuficiente en las áreas protegidas vírgenes que regularmente son utilizadas por grupos con ganado recreativo. Los manejadores de estas áreas necesitan monitorear las condiciones de la paradera y las intensidades de apacentamiento que ocurren. Nuestro estudio sugiere que la biomasa y la cobertura vegetal son indicadores mas sensitivos del impacto del apacentamiento que la composición de especies. Los manejadores deben tomar decisiones acerca de los niveles máximos aceptables del impacto del apacentamiento y entonces desarrollar guías para los niveles máximos de uso basadas en datos tales como los nuestros que relacionan la intensidad de apacentamiento con la respuesta de la pradera.

where meadows are a common and valued component of the landscape. In most mountainous wilderness areas, a minority of visitors use pack stock (mostly horses and mules, but occasionally burros and recently llamas and goats) for transport into remote areas (McClaran and Cole 1993, McClaran 2000). On these trips, animals are commonly kept overnight and allowed to graze in mountain meadows. 
The mandate to preserve natural conditions in wilderness has usually been interpreted to mean that activities of modern humans, including recreational visitors and their pack stock, should have little effect on ecosystems. Therefore, where travel with pack stock is judged to be an appropriate use of wilderness, pack stock grazing should be managed such that impacts to meadows do not exceed acceptable levels. Grazing impacts in wilderness are seldom monitored and stock use is largely unregulated (McClaran and Cole 1993). This suggests that either the modest levels of grazing that typically occur in wilderness have a negligible effect on meadow characteristics or pack stock grazing is not receiving the management attention it deserves.

The vast majority of research on grazing impacts to mountain meadows has occurred in situations where management objectives are concerned more with sustainable use and production than with preservation of natural conditions. Standards and grazing systems (including utilization levels) developed for such situations are probably inappropriate in wilderness, given its more stringent preservation objectives. Consequently, wilderness managers lack the information they need to assess the degree to which pack stock grazing is a management concern and to develop standards, monitoring protocols, and management systems that are appropriate for wilderness.

Our 5-year field study was designed to contribute to the empirical foundation for management of pack stock grazing in wilderness mountain meadows. Specifically, we assessed the magnitude of changes in biomass production, ground cover, and species composition resulting from grazing by horses and mules at the relatively low intensities that are typical of recreational use in wilderness. Where grazing had an effect, we evaluated the extent to which the magnitude of effect was related to grazing intensity.

\section{Materials and Methods}

\section{Study Sites}

The study was conducted in 3 meadows characteristic of common upper montane and subalpine meadow types in Yosemite National Park and the Sierra Nevada, California. The highest elevation meadow, in the Gaylor Lakes basin $(3,100 \mathrm{~m}$, $37^{\circ} 54^{\prime} 30^{\prime \prime} \mathrm{N}, 119^{\circ} 17^{\prime} 0^{\prime \prime} \mathrm{W}$ ), is representative of the Carex exserta MacKenzie (shorthair sedge) series of Sierra Nevada meadows as defined by Ratliff (1985).
Using the nomenclature of Hickman (1993), shorthair sedge is now Carex filifolia Nutt. var. erostrata Kük. This meadow type is characteristic of xeric slopes and benches in the upper subalpine zone throughout much of the Sierra Nevada. The ground cover is an intricate mosaic of dense sod, broken by exposed rock and patches of gravel and mineral soil. Aerial vegetation cover on our study plots was about $50 \%$, with shorthair sedge accounting for $72 \%$ of the cover. Alpine pussytoes (Antennaria media E. Greene), Brewer's reed grass (Calamagrostis breweri Thurber), northern goldenrod (Solidago multiradiata Aiton), mountain dandelion [Agoseris glauca (Pursh) Raf.], dwarf lupine (Lupinus lepidus Douglas), and Stebbins' bluegrass (Poa stebbinsii R. Soreng) are the most abundant associated species. Mean peak biomass varied between 58 and $77 \mathrm{~g} \mathrm{~m}^{-2}$ over the 5 years of the study. This meadow has not experienced significant grazing since 1890 . Prior to then, the meadow was probably heavily grazed by sheep, although there is no documentation of numbers.

The second site, within Tuolumne Meadows $\left(2,600 \mathrm{~m}, 37^{\circ} 53^{\prime} 0^{\prime \prime} \mathrm{N}\right.$, $\left.119^{\circ} 23^{\prime} 0^{\prime \prime} \mathrm{W}\right)$, is representative of the Calamagrostis breweri (shorthair) series (Ratliff 1985). This type, the Brewer's reed grass type, is typical of mesic basin sites throughout the subalpine zone and often occurs immediately below the shorthair sedge meadow type. Aerial vegetative cover is nearly continuous, with occasional patches of exposed mineral soil. Although dominated by short caespitose grasses, particularly Brewer's reed grass ( $45 \%$ of the cover) and intermediate oatgrass (Danthonia intermedia Vasey) (12\%), species composition is diverse. Abundant associated species include meadow everlasting (Antennaria corymbosa E. Nelson), alpine aster [Aster alpigenus (Torrey \& A. Gray) A. Gray var. andersonii (A. Gray) M. Peck], Newberry's gentian (Gentiana newberryi A. Gray), western dog violet (Viola adunca Smith), and dwarf bilberry (Vaccinium caespitosum Michaux). Mean peak biomass varied between 168 and $368 \mathrm{~g} \mathrm{~m}^{-2}$ over the 5 years of the study. This meadow has not been grazed since 1910. Before the turn of the century, it was heavily grazed by sheep, although there is no documentation of numbers.

The third site, close to Harden Lake $\left(2,285 \mathrm{~m}, 37^{\circ} 53^{\prime} 30^{\prime \prime} \mathrm{N}, 11^{\circ} 41^{\prime} 0^{\prime \prime} \mathrm{W}\right)$, is representative of the Deschampsia cespitosa (tufted hairgrass) series, which is typical of mesic basin sites in the upper mon- tane and lower subalpine zone (Ratliff 1985). The vegetative canopy cover is nearly continuous and dominated by dense growth of medium-tall graminoids, tufted hairgass, and several sedge species. Common associated species are diverse and include pull-up muhly [Muhlenbergia filiformis (Thurber) Rydb.], alpine aster, western mountain aster [Aster occidentalis (Nutt.) Torrey \& A. Gray], and tinker's penny (Hypericum anagalloides Cham. \& Schildl.). Mean peak biomass varied between 280 and $448 \mathrm{~g} \mathrm{~m}^{-2}$ over the 5 years of the study. The portion of the meadow we studied has seldom received much grazing. In the $1880 \mathrm{~s}$, the meadow was close to a homestead and may have been grazed by cattle.

\section{Field Methods}

In each meadow, we established 16,8 by $-8 \mathrm{~m}$ plots, clustered 4 to a block in 4 separate blocks. Each block contained a control plot which was not grazed. The other plots were randomly assigned a target utilization treatment of 25,50 , or $75 \%$. Grazing treatments were applied close to the time of peak biomass, in July and August, or August and September (depending on time of snowmelt) in 1994, 1995, 1996, and 1997. Horses or mules were picketed on 4-m ropes, producing a $\sim 50 \mathrm{~m}^{2}$ circular grazed area. We recorded the length of time animals were on the treatment plots. In practice, it was not possible to judge forage removal accurately enough to terminate grazing at the exact utilization targets. Nor was it feasible to keep stock interested in grazing long enough to utilize $75 \%$ of the biomass. Consequently, percent utilization varied continuously across plots. Because utilization varied somewhat between years on the same plot, grazing treatments are expressed as the mean of the 4 years of treatment on each plot.

Some modifications to this design were necessary because near-record snowfall occurred in the winters following the first and last seasons of grazing (1994-1995 and 1997-1998). Although the 30-year mean snow depth at Tuolumne Meadows, near the Brewer's reed grass meadow, is $149 \mathrm{~cm}$, on 1 April 1995, it was $271 \mathrm{~cm}$, and on 1 April 1998, it was $235 \mathrm{~cm}$. In 1995, pre-grazing measurements were not initiated on any of the meadows until midAugust. In the tufted hairgrass meadow, aerial cover measurements were not made that year, so species composition could not be determined. Moreover, 1 of the blocks in the tufted hairgrass meadow was dropped because it was excessively wet. In 
1998 in the tufted hairgrass meadow, standing water persisted on the plots through September. The measurements made on that meadow for that year were not considered reliable and were omitted.

In each plot, we estimated aboveground biomass, basal cover, and aerial cover of each species within 10 randomly located $0.125 \mathrm{~m}^{2}$ quadrats. Measurements were made each year that grazing occurred, as well as in 1998, one year after the final grazing treatment. Biomass and basal cover were estimated before and within 1 week after grazing sessions, while aerial cover was estimated only before grazing sessions. A different set of 10 quadrats was established in each plot for each measurement period to avoid resampling clipped plots. All cover estimates were made before biomass was clipped. Basal cover was assessed with a 5-pin frame systematically placed 4 times within each quadrat (total of 20 pins). For each pin, we recorded the cover category the pin contacted at ground level: live vascular vegetation, live nonvascular vegetation, litter, bare soil, gravel, or rock. Aerial cover was assessed using the same 20 pins per quadrat. We recorded each species hit by the pin as it was dropped from above the canopy to the ground surface, not just the first species. Biomass was estimated by clipping vegetation to a height of about 1 $\mathrm{cm}$ above the ground surface. Clipped vegetation was dried at approximately $60^{\circ}$ $\mathrm{C}$ until weight stabilized, and then weighed.

\section{Analysis}

Estimates of percent utilization for each plot and year of treatment were based on the difference in biomass before and after grazing for each year of treatment, adjusted for changes in biomass on the ungrazed plots.

$$
\begin{aligned}
& \text { Percent utilization }= \\
& \left(1-\left(\left(A_{\text {treatment }} \div B_{\text {treatment }}\right) \div\right.\right. \\
& \left.\left(A_{\text {ungrazed }} B_{\text {ungrazed }}\right)\right) \times 100,
\end{aligned}
$$

where $\mathrm{B}_{\text {treatment }}$ and $\mathrm{A}_{\text {treatment }}$ are biomass before and after grazing on grazed plots, and $\mathrm{B}_{\text {ungrazed }}$ and $\mathrm{A}_{\text {ungrazed }}$ are biomass before and after grazing on the ungrazed plot in the same block. To assess the effects of more than 1 season of grazing, we used the mean percent utilization from all previous years as a cumulative estimate of grazing intensity.

Meadow response variables were biomass, basal vascular vegetation cover, bare soil cover, basal litter cover, relative graminoid cover, and floristic dissimilarity. Biomass and basal cover are direct measures. Relative graminoid cover and floristic dissimilarity are synthetic variables indicative of change in species composition. Relative graminoid cover is the sum of the cover of all graminoid species divided by the sum of the cover of all vascular species. Each individual species' cover is the proportion of 200 pins in each plot that hit that species. Floristic dissimilarity, a modification of Sorensen's similarity indices (Mueller-Dombois and Ellenberg 1974), provides an estimate of the difference in species composition between 2 measurement periods. We calculated the floristic difference between plots before and 1 year following grazing:

\section{Floristic Dissimilarity =}

$$
0.5 \sum_{i=I}^{n}\left|p_{\text {before }}(\mathrm{i})-p_{\text {after }}(i)\right|
$$

where $n$ is the number of species and $p_{b e}$ fore $(i)$ and $p_{\text {after }}(i)$ are the relative covers for species $i$ on the same plots, before and after grazing. Relative cover is the cover of a given species divided by the sum of the cover of all species.

To assess whether grazing altered meadow characteristics, we conducted paired ttests, comparing change in each variable on grazed and ungrazed plots. For biomass, basal vascular vegetation cover, basal litter cover, and relative graminoid cover, change was the post-grazing condition (those that existed 1 year after the final grazing treatment) minus pre-grazing condition, as a percentage of the pre-grazing condition. For bare soil cover, this index could not be used because initial cover values were occasionally zero. For bare soil, the index of change was the post-grazing condition minus the pre-grazing condition. Floristic dissimilarity is an index of change over time, so no adjustment was needed. In this and all other tests, we considered differences to be statistically significant where $P \leq 0.05$.

As an indicator of the magnitude of change attributable to grazing, post-grazing conditions were expressed as a percentage of pre-grazing conditions and then adjusted for changes on ungrazed plots. For biomass, basal vascular vegetation cover, bare soil cover, basal litter cover, and relative graminoid cover, the index of change attributable to grazing is:

$$
\begin{aligned}
& \text { Index }=\left(\left(P_{\text {treatment }} \div I_{\text {treatment }}\right) \div\right. \\
& \left.\left(P_{\text {ungrazed }} \div I_{\text {ungrazed }}\right)\right) \times 100 \quad(\text { Eq. } 3)
\end{aligned}
$$

where $I_{\text {treatment }}$ and $I_{\text {ungrazed }}$ are the initial (1994) conditions on grazed and ungrazed plots, respectively, and $P_{\text {treatment }}$ and $P_{\text {ungrazed }}$ are the post-grazing conditions on grazed and ungrazed plots, respectively.
Values smaller than $100 \%$ indicate decreases attributable to grazing, while values larger than $100 \%$ indicate increases.

For bare soil cover, the index was calculated from:

$$
\begin{aligned}
& \text { Index }=\left(\left(P_{\text {treatment }}-I_{\text {treatment }}\right)-\right. \\
& \left.\left(P_{\text {ungrazed }}-I_{\text {ungrazed }}\right)\right) \times 100 .
\end{aligned}
$$

Positive values indicate an increase in bare soil cover attributable to grazing, while negative values indicate a decrease.

For floristic dissimilarity (FD), we calculated the index using:

$$
\text { Index }=F D_{\text {treatment }}-F D_{\text {ungrazed }}
$$

Positive values indicate an increase in compositional change resulting from grazing, while negative values indicate a decrease.

The original research design was a randomized complete block with 3 grazing treatments $(25,50$, and $75 \%$ forage utilization) and an ungrazed control, repeatedly measured over 5 years in each of the 3 meadows. Each meadow was to be analyzed separately. Because designed levels of grazing intensity could not be achieved, we used percent utilization as a covariate rather than a treatment factor in the analysis of variance. Because the plots were measured repeatedly over time, it was necessary to adjust for serial correlation in the repeated measures. The Akaike Information Criterion (AIC) indicated that a first order autoregressive covariance structure, AR(1), provided the best fit to the data. The estimated covariance structure is incorporated into estimates of standard errors for regression coefficients, least squares means, and differences in least squares means by PROC MIXED in SAS 8.1 (Littell et al. 1996). For those meadow response characteristics that are significantly related to utilization, we provide regression equations, coefficients of determination $\left(r^{2}\right)$, and scatter plots to illustrate the nature of the relationship. Data from the first season of grazing were excluded from these analyses because effects were generally small.

\section{Results}

The grazing intensity of treatments varied among meadows, plots, and years. On plots in the shorthair sedge meadow, utilization varied between 26 and $60 \%$ with a mean of $41 \%$. The mean length of time animals were picketed on plots was 146 minutes per year. In the Brewer's reed grass meadow, utilization varied between 
15 and $52 \%$, with a mean of $35 \%$ (351 min year $\left.^{-1}\right)$. In the tufted hairgrass meadow, utilization varied between 31 and $69 \%$, with a mean of $49 \%$ ( 587 min year $^{-1}$ ).

\section{Comparison of Grazed and Ungrazed Plots}

Most meadow characteristics varied among years on both grazed and ungrazed plots (Fig. 1). Biomass and basal vegetation cover declined during the first year of the experiment, even on ungrazed plots, in response to the heavy snow season and subsequent flooding during the 1994-1995 winter (between Year 0 and Year 1). Many characteristics, particularly basal vegetation and bare soil cover, also varied among plots prior to treatment. This temporal and spatial variation illustrates the need to base interpretations on indices of change over time and on change resulting from grazing.

One year after the first season of grazing, biomass was similar on grazed and
$17 \%$ in the Brewer's reed grass meadow, and $22 \%$ in the tufted hairgrass meadow.

Grazing resulted in increases in basal bare soil cover in each meadow (Table 1, Fig. 1). The mean increase in bare soil cover attributable to 4 years of grazing was $13 \%$ in the Brewer's reed grass and tufted hairgrass meadows and $7 \%$ in the shorthair sedge meadow. Only in the shorthair sedge meadow were decreases in basal vegetation cover over time clearly a result of grazing. In this meadow, pregrazing basal vegetation cover was greater on treated plots than on ungrazed control plots (Fig.1). As the study progressed, however, basal vegetation cover declined on grazed plots and increased or stayed the same on ungrazed plots. One year after the final season of grazing, grazed plots had less vegetation cover than ungrazed plots (Table 1). Basal litter cover was relatively constant among years in this meadow and differed little between grazed and ungrazed plots (Table 1, Fig. 1).
(Table 1). Increases in litter cover over the 5 years of the study were less pronounced on the grazed plots (Table 1).

In the tufted hairgrass meadow, as the experiment progressed, vegetation cover declined on grazed plots and was unchanged on ungrazed plots (Fig. 1). One year after the final year of grazing, however, differences were not statistically significant (Table 1). Litter cover declined over time but the magnitude of change differed little between grazed and ungrazed plots.

Grazing also affected the species composition of each meadow. Floristic dissimilarity was greater on grazed plots than on ungrazed plots, after each season of grazing except the first (Fig. 1). One year following the final treatment year, differences between grazed and ungrazed plots were statistically significant in each meadow (Table 1). The nature of the compositional shift resulting from grazing was explored by examining differences

Table 1. Comparison between grazed and ungrazed plots in the mean change in meadow characteristics that occurred between initial conditions and conditions 1 year after the final grazing application'.

\begin{tabular}{|c|c|c|c|c|c|c|c|c|c|}
\hline \multirow[t]{2}{*}{ Characteristic } & \multicolumn{3}{|c|}{ Shorthair Sedge } & \multicolumn{3}{|c|}{ Brewer's Reed Grass } & \multicolumn{3}{|c|}{ Tufted Hairgrass } \\
\hline & Grazed & Ungrazed & P-value ${ }^{2}$ & Grazed & Ungrazed & P-value ${ }^{2}$ & Grazed & Ungrazed & P-value ${ }^{2}$ \\
\hline Biomass & -36 & -25 & $<0.01$ & -55 & -48 & $<0.01$ & -27 & 2 & $<0.01$ \\
\hline Basal Soil Cover & 6 & -1 & 0.01 & 19 & 6 & $<0.01$ & 1 & -3 & 0.05 \\
\hline Basal Vegetation Cover & -36 & 11 & $<0.01$ & -69 & -77 & 0.04 & 12 & 0 & 0.28 \\
\hline Basal Litter Cover & -6 & -6 & 0.47 & 10 & 55 & $<0.01$ & -23 & -28 & 0.19 \\
\hline Floristic Dissimilarity & 25 & 17 & $<0.01$ & 31 & 26 & 0.05 & 38 & 32 & 0.05 \\
\hline Relative Graminoid Cover & -10 & -7 & 0.30 & -27 & -7 & $<0.01$ & -7 & -1 & 0.14 \\
\hline
\end{tabular}

${ }^{1}$ Change values are post-grazing condition minus pre-grazing condition, as a percentage of initial conditions. For bare soil cover, change values are post-grazing conditions minus initial conditions. For floristic dissimilarity, change values are treatment conditions minus control conditions.

${ }^{2}$ Results of t-test from paired sample comparison.

ungrazed plots (Fig. 1). However, after the second, third, and fourth seasons of grazing, grazed plots had less biomass than ungrazed plots in all 3 meadows. Reductions in biomass on grazed plots, 1 year after the final year of grazing, were greater than reductions on ungrazed plots (Table 1), suggesting that grazing reduced the productivity of each meadow. The mean reduction after 4 years of grazing was $18 \%$ in the shorthair sedge meadow,
In the Brewer's reed grass meadow, basal vegetation cover decreased and litter cover increased on both grazed and ungrazed plots in the aftermath of meadow flooding and sediment deposition after the first year of the study (Fig. 1). However, grazing did not exacerbate the decline in vegetation cover. One year after the final year of grazing, reduction in basal vegetation cover on grazed plots was less pronounced than reduction on ungrazed plots between grazed and ungrazed plots in cover of individual species and life forms. The only consistent change that emerged was a decline in relative graminoid cover on grazed plots in each of the 3 meadows (Fig. 1). After the final season of grazing, however, differences between grazed and ungrazed plots were significant only in the Brewer's reed grass meadow (Table 1).

Table 2. Analysis of variance results (P-values) for the effect of percent utilization, years of grazing, and the interaction between utilization and years on change in meadow characteristics resulting from grazing.

\begin{tabular}{|c|c|c|c|c|c|c|c|c|c|}
\hline \multirow[t]{2}{*}{ Characteristic } & \multicolumn{3}{|c|}{ Shorthair Sedge } & \multicolumn{3}{|c|}{ Brewer's Reed Grass } & \multicolumn{3}{|c|}{$\begin{array}{c}\text { Tufted Hairgrass } \\
\end{array}$} \\
\hline & Utilization & Years & Interaction & Utilization & Years & Interaction & Utilization & Years & Interaction \\
\hline Biomass & $<0.01$ & 0.61 & 0.38 & $<0.01$ & 0.51 & 0.03 & 0.01 & 0.90 & 0.32 \\
\hline Basal Vegetation Cover & $<0.01$ & 0.74 & 0.92 & $<0.01$ & $<0.01$ & $<0.01$ & 0.24 & 0.27 & 0.08 \\
\hline Basal Soil Cover & 0.18 & 0.97 & 0.99 & $<0.01$ & 0.39 & 0.64 & 0.93 & 0.62 & 0.95 \\
\hline Basal Litter Cover & 0.16 & 0.86 & 0.63 & 0.49 & 0.43 & 0.23 & 0.36 & 0.24 & 0.14 \\
\hline Floristic Dissimilarity & 0.42 & 0.06 & 0.42 & 0.06 & 0.24 & 0.28 & 0.10 & 0.24 & 0.97 \\
\hline Relative Graminoid Cover & 0.15 & 0.42 & 0.29 & 0.05 & 0.04 & 0.10 & 0.26 & 0.88 & 0.98 \\
\hline
\end{tabular}


Shorthair Sedge Meadow
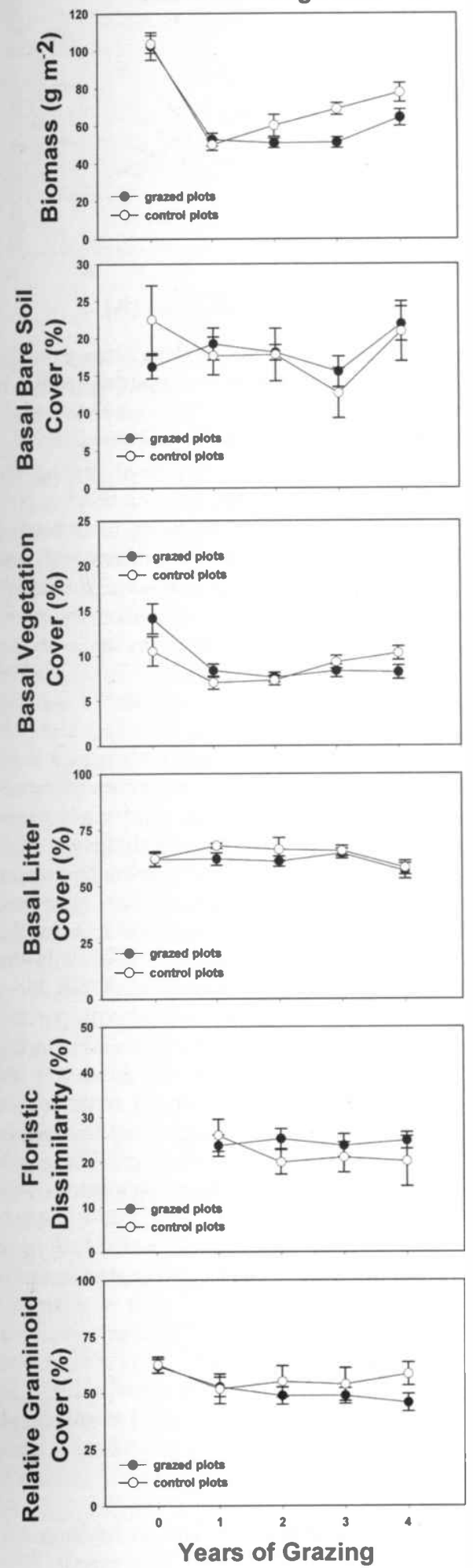

Brewer's Reed Grass Meadow
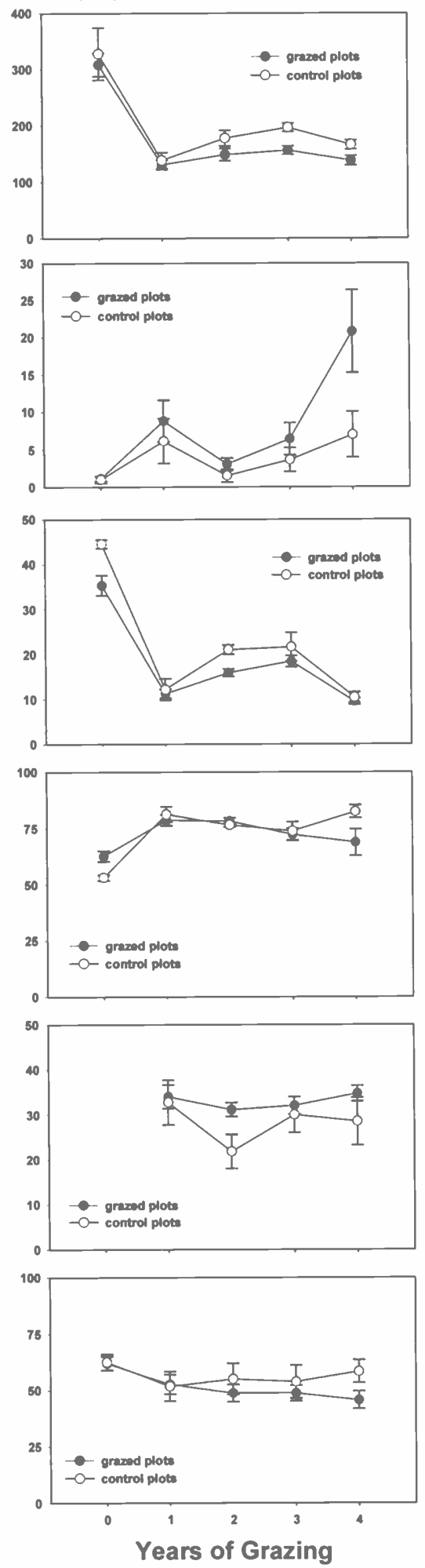

Tufted Hairgrass Meadow
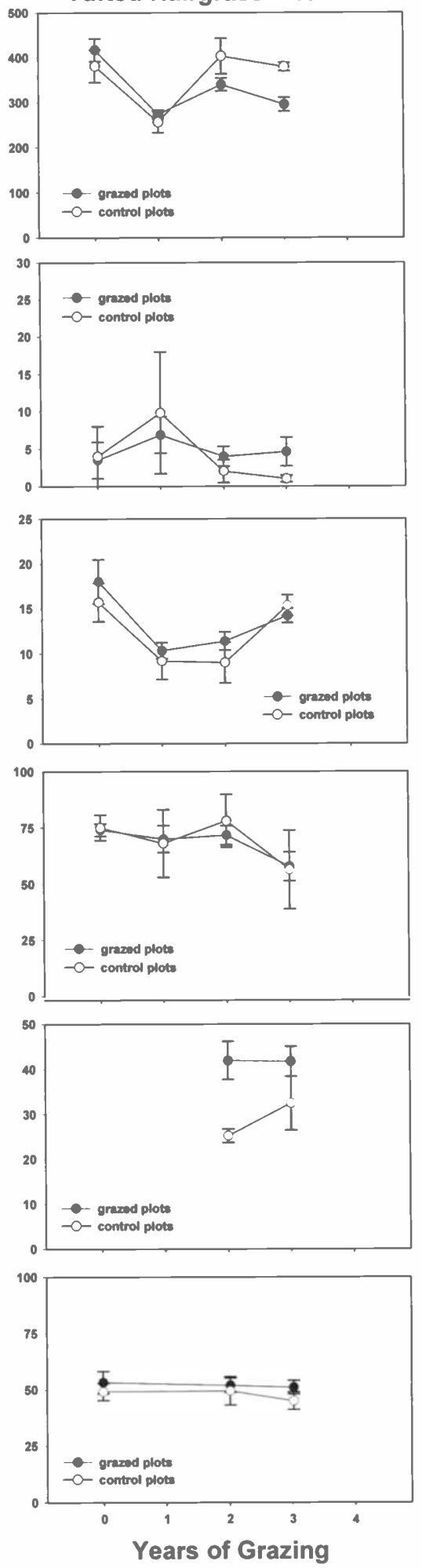

Fig. 1. Meadow conditions (mean $\pm 1 \mathrm{SE}$ ) on grazed and ungrazed plots in 3 meadows. Values are given for conditions before grazing (year 0 ), as well as 1 year after $1,2,3$, and 4 successive seasons of grazing. 
Shorthair Sedge Meadow

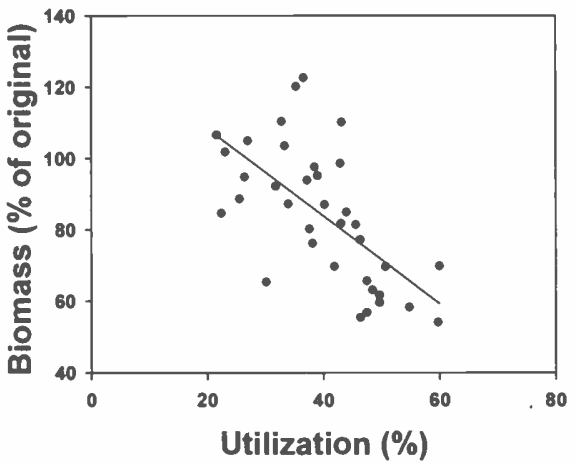

Brewer's Reed Grass Meadow

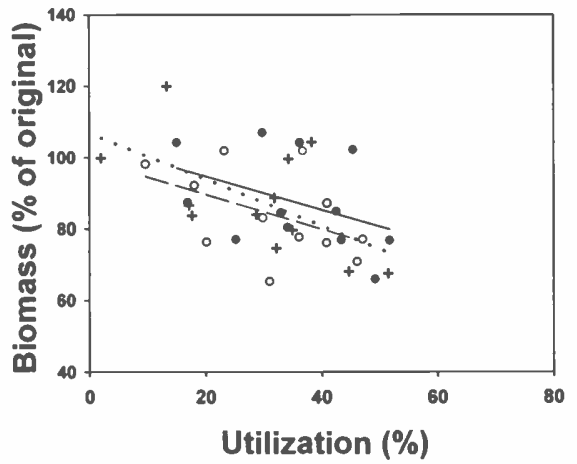

Tufted Hairgrass Meadow

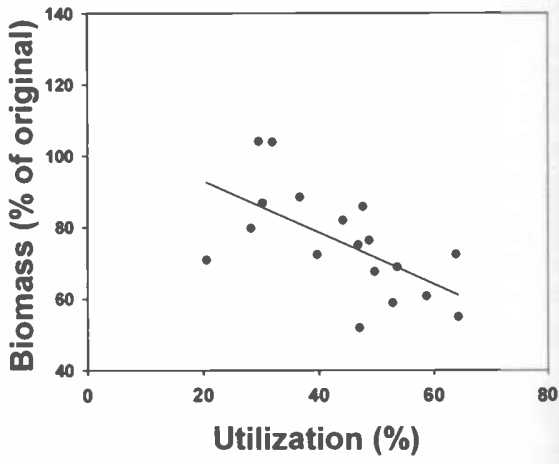

Fig. 2. Scatterplots and regression lines for significant relationships between percent utilization and meadow productivity (change in biomass), 1 year after 2 (crosshairs and dotted line), 3 (open circles and dashed line), and 4 (solid circles and solid line) years of grazing. If there were no significant year effects or interactions, the data were collapsed into a single solid line.

\section{Effect of Utilization on Magnitude of Change}

In all 3 meadows, productivity decreased as percent utilization increased (Table 2, Fig. 2). The effect of grazing intensity was greatest in the shorthair sedge meadow, although this was also the meadow least affected by light grazing. Regression equations, in which $\mathrm{x}$ is percent utilization and $y$ is percent of original biomass, were $y=133-1.23 x\left(r^{2}=0.41\right)$ in the shorthair sedge meadow and $\mathrm{y}=$ $107-0.72 x\left(r^{2}=0.37\right)$ in the tufted hairgrass meadow. Utilization and years grazed interacted in the Brewer's reed grass meadow. Consequently, separate regression equations were developed for 2,3 , and 4 years of grazing. Equations were $y=106-0.65 x\left(r^{2}=0.34\right), y=99-$ $0.49 x\left(r^{2}=0.22\right)$, and $y=104-0.47 x\left(r^{2}=\right.$ 0.17 ), respectively.

Relationships between grazing intensity and ground cover were less consistent. In all 3 meadows, increases in grazing inten- sity were associated with increases in bare soil and decreases in both vegetation and litter cover. However, litter cover did not vary with percent utilization in any of the meadows and bare soil cover did not vary with percent utilization in either the shorthair sedge or tufted hairgrass meadows (Table 2). In the Brewer's reed grass meadow, bare soil increased as percent utilization increased (Fig. 3), but the resultant regression equation was a poor predictor of magnitude of change $(y=1.4+$ $0.14 x, r^{2}=0.03$ ).

Change in vegetation cover varied with utilization in the shorthair sedge and Brewer's reed grass meadows (Fig. 4). Low levels of grazing increased vegetation cover, particularly in the Brewer's reed grass meadow, while higher grazing intensities reduced vegetation cover. The regression equation for the shorthair sedge meadow was $y=165-2.32 x\left(r^{2}=0.38\right)$. In the Brewer's reed grass meadow, utilization interacted with years of grazing.

\section{Brewer's Reed Grass Meadow}

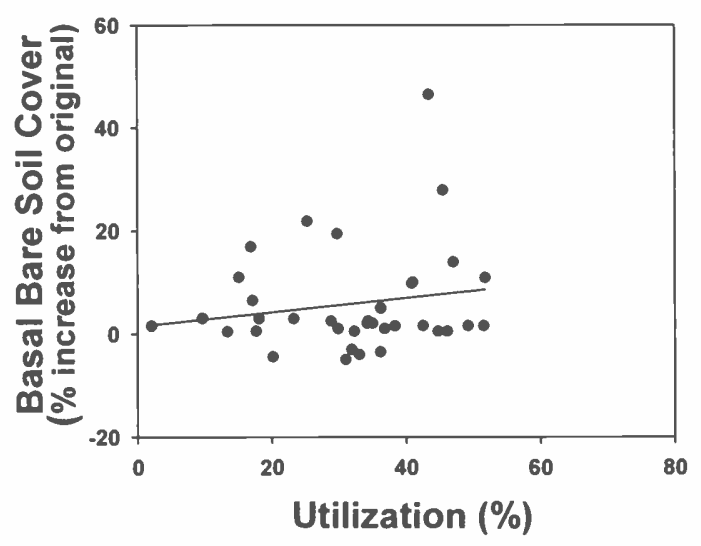

Fig. 3. Scatterplot and regression line for the significant relationship between percent utilization and change in basal bare soil cover in the Brewer's reed grass meadow.
With each successive year of grazing, the effect of grazing intensity on basal vegetation cover became more pronounced (slopes of regression lines increased) and more predictable (coefficients of determination increased). Regression equations after 2,3 , and 4 years of grazing were $y=$ $166-1.93 x\left(r^{2}=0.52\right), y=211-2.87 x\left(r^{2}\right.$ $=0.62)$, and $y=250-3.35 x\left(r^{2}=0.68\right)$, respectively.

Changes in species composition were even less predictably related to differences in grazing intensity. In the Brewer's reed grass and tufted hairgrass meadows, compositional change attributable to grazing increased as percent utilization increased, but $\mathrm{P}$-values did not meet our criterion for statistical significance (Table 2). In the shorthair sedge meadow, changes in floristic dissimilarity decreased with percent utilization, but not significantly. In the Brewer's reed grass meadow, relative graminoid cover decreased as utilization increased (Fig. 5), suggesting that higher grazing intensities reduce graminoid/forb ratios. However, there was interaction between utilization and years grazed. Regression equations for individual years indicate that this relationship was less pronounced after the fourth year of grazing $(y$ $\left.=84-0.16 x, r^{2}=0.01\right)$, than it was after the second $\left(y=101-0.39 x, r^{2}=0.19\right)$ and third year $\left(y=118-0.83 x, r^{2}=0.39\right)$. In the other 2 meadows, relative graminoid cover did not vary with utilization.

\section{Discussion and Conclusions}

Grazing by recreational pack and saddle stock, even at intensities as modest as a few hours per year on picket, reduced the productivity (peak standing biomass), basal vegetation cover, basal litter cover 

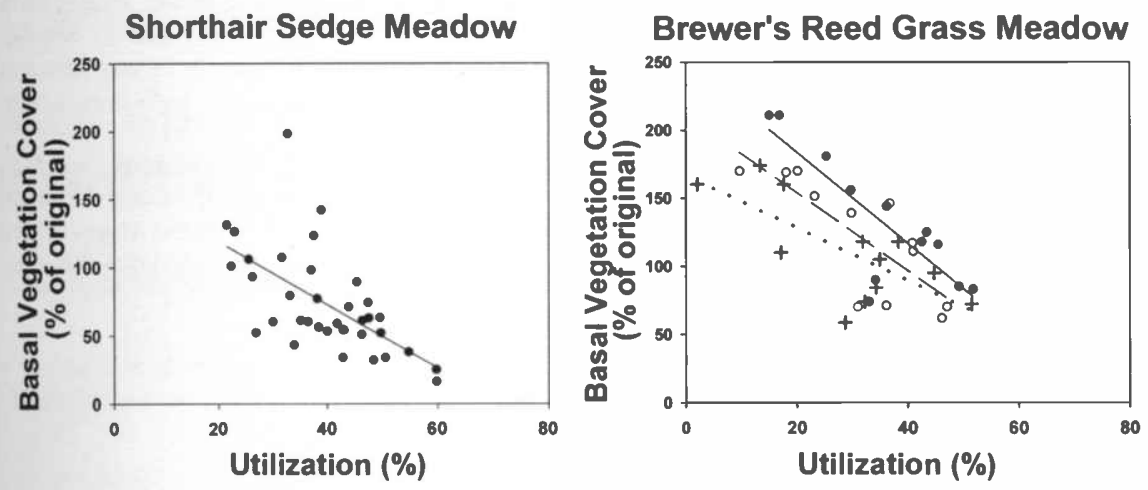

Fig. 4. Scatterplots and regression lines for significant relationships between percent utilization and change in basal vegetation cover, 1 year after 2 (crosshairs and dotted line), 3 (open circles and dashed line), and 4 (solid circles and solid line) years of grazing. If there were no significant year effects or interactions, the data were collapsed into a single solid line.

and relative graminoid cover, increased the basal soil cover, and altered the species composition of these meadows. Concern about overgrazing of mountain meadows by recreational pack stock has been voiced since at least the 1930 s (Sumner 1936) and grazing was prohibited in a few meadows in Yosemite National Park in the 1960s (Sharsmith 1961). However, our data are among the first to demonstrate that grazing, at intensities that are typical of recreational groups, can compromise the naturalness of wilderness mountain meadows.

Our results are generally consistent with those of several earlier studies. Stohlgren et al. (1989), working in shorthair sedge, Brewer's reed grass, and tufted hairgrass meadows in Sequoia-Kings Canyon Wilderness in the Sierra Nevada, found that biomass production decreased as the intensity of defoliation by clipping increased. In mountain meadows in a Montana wilderness, Olson-Rutz et al. (1996a) found that bare soil increased and vegetation cover decreased as the duration of grazing by pack stock increased. The reduction of relative graminoid cover we found in the tufted hairgrass meadow is consistent with evidence that horses prefer to graze graminoids over forbs until forage becomes limiting, after about 8 hours on a $7.5-\mathrm{m}$ picket rope (Olson-Rutz et al. 1996b) (equivalent to 2.5 hours on the 4$\mathrm{m}$ picket rope we used), or after the amount of grass biomass removed reaches 65\% (Reiner and Urness 1982).

Few guidelines exist for appropriate grazing intensities for high elevation meadows, whether in protected areas like wilderness or not. Ratliff et al. (1987) proposed utilization levels of $35 \%$ in dry and $45 \%$ in mesic Sierra Nevada alpine meadstock affects meadow conditions, wilderness managers must develop guidelines for how much grazing and impact to allow. They must decide how to balance the conflicting objectives of providing recreational opportunities, including use of pack and saddle stock, and preserving meadows in their undisturbed state. Guidelines developed for production livestock grazing systems may not be appropriate within protected areas, where objectives stress preservation of natural conditions. Wilderness managers might decide, for example, that they should not allow meadow productivity to decrease more than $10 \%$ in order to accommodate grazing by recreational pack stock.
Our data show that, in order to limit grazing impact to these levels, percent utilization should not exceed about $35 \%$ in the shorthair sedge meadow or about $25 \%$ in the Brewer's reed grass and tufted hairgrass meadows. To avoid exceeding these utilization levels, grazing would have to be limited to no more than a few hours per year in areas as small as our $50-\mathrm{m}^{2}$ grazing plots.

This suggests that meadows can be maintained in a relatively undisturbed condition where pack stock use is low, but that substantial alteration of meadow conditions is likely wherever meadows receive even moderate levels of repeated grazing. Passive management may be adequate where stock use is low, meadows are large, and grazing impact is widely dispersed, but monitoring programs and regulations on use are needed in most wilderness areas that receive regular stock use. Impacts may be difficult to avoid in popular locations where stock are kept overnight, particularly where meadows are small, such as at lakes in cirque basins. Stock management may be more difficult where there is frequent overnight use by private groups using their own animals. Compared to commercial and administrative groups, private stock users may be less experienced and, therefore, more likely to confine their animals in small spaces and overgraze meadows. Their use distribution is more unpredictable and less subject to control and they are more difficult to communicate with.

One of the keys to improved management of recreational stock in parks and wilderness is development of routine mon-

Given that recreational grazing of pack

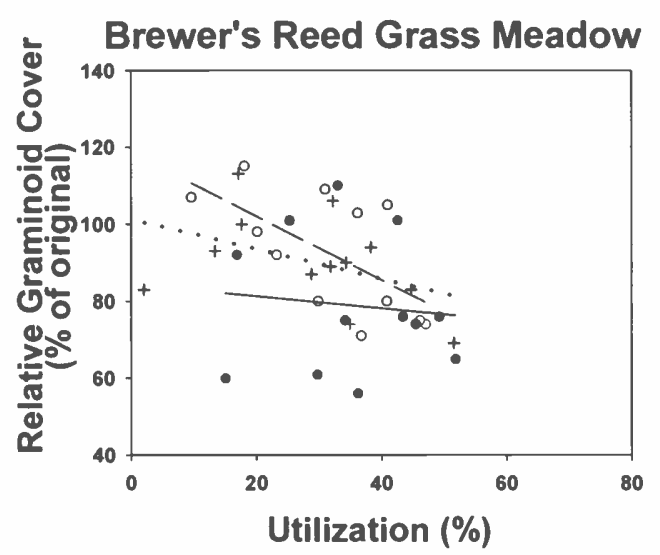

Fig. 5. Scatterplots and regression lines for the significant relationship between percent utilization and change in relative graminoid cover, 1 year after 2 (crosshairs and dotted line), 3 (open circles and dashed line), and 4 (solid circles and solid line) years of grazing, in the Brewer's reed grass meadow. 
itoring programs (McClaran and Cole 1993). Our results indicate that productivity and, to a lesser degree, basal vegetation and soil cover respond consistently and rapidly to increased grazing pressure. These parameters appear to be more sensitive indicators of meadow condition than species composition, where grazing intensity and impact are modest. However, given the spatial and temporal heterogeneity of conditions in these meadows, attributing change in condition to grazing is problematic. This suggests that, in addition to monitoring meadow characteristics, monitoring programs should also include measurements of grazing intensity, such as percent utilization. Utilization estimates are also challenging to derive given the need to estimate biomass more than once during the season, the variability in grazing intensity that occurs within individual meadows, and the costs of monitoring remote, widely dispersed meadows.

Ultimately, given the difficulties of regularly monitoring both grazing intensity and meadow characteristics throughout a wilderness area, it might be more fruitful to develop guidelines for animal nights per year for individual meadows. To do this, managers would first need to make decisions about maximum acceptable alteration of meadow conditions (e.g. $\leq 10 \%$ decrease in meadow productivity). Then they could utilize information about empirical relationships, such as those we developed for percent utilization and meadow productivity, to establish limits on grazing intensity. The final step would involve estimates of the animal nights per year that individual meadows could sustain without exceeding these grazing intensity limits. Such estimates would need to consider many variables such as meadow size, campsite numbers and locations, typical stock confinement techniques, etc. Although such estimates are likely to be imprecise at first, they can be adjusted as needed based on monitoring data of grazing intensity and meadow condition.

\section{Literature Cited}

Hickman, J.C. ed. 1993. The Jepson manual: Higher plants of California. Univ. California Press, Berkeley, Calif.

Littell, R.C., G.A. Milliken, W.W. Stroup, and R.D. Russell. 1996. SAS system for mixed models. SAS Institute Inc, Cary, N.C.

McClaran, M.P. 2000. Improving livestock management in wilderness, p. 49-63. In: D.N. Cole, S.F. McCool, W.T. Borrie and J.O'Loughlin (comps.) Wilderness science in a time of change. Volume 5: Wilderness Ecosystems, Threats, and Management. USDA For. Serv. Proc. RMRS-P-15-VOL-5. Ogden, Ut.

McClaran, M.P. and D.N. Cole. 1993. Packstock in wilderness: Use, impacts, monitoring and management. USDA For. Serv. Gen. Tech. Rep. INT-301. Ogden, Ut.

Mueller-Dombois, D. and H. Ellenberg. 1974. Aims and methods of vegetation ecology. John Wiley \& Sons, New York, N.Y.

Olson-Rutz, K.M., C.B. Marlow, K. Hansen, L.C. Gagnon, and R.J. Rossi. 1996a. Recovery of a high elevation plant community after packhorse grazing. J. Range Manage. 49:541-545.

Olson-Rutz, K.M., C.B. Marlow, K. Hansen, L.C. Gagnon, and R.J. Rossi. 1996b. Packstock grazing behavior and immediate impact on a timberline meadow. J. Range Manage. 49:546-550.

Ratliff, R.D. 1985. Meadows in the Sierra Nevada of California: State of knowledge. USDA Forest Serv. Gen. Tech. Rep. PSW84. Berkeley, Calif.

Ratliff, R.D., M.R. George, and N.K. McDougald. 1987. Managing livestock grazing on meadows of California's Sierra Nevada. Univ. of California Coop. Ext. Leaflet 21421, Davis, Calif.

Reiner, R.J. and P.J. Urness. 1982. Effect of grazing horses managed as manipulators of big game winter range. J. Range Manage. 35:567-571.

Sharsmith, C.W. 1961. A report on the status, changes and comparative ecology of selected backcountry meadow areas in Yosemite National Park that receive heavy visitor use. National Park Service, Yosemite, Calif.
Sumner, E. L. 1936. Special report on a wildlife study of the High Sierra in Sequoia and Yosemite National Parks and adjacent territory. National Park Service, San Francisco, Calif.

Stohlgren, T.J., S.H. DeBenedetti, and D.J. Parsons. 1989. Effects of herbage removal on productivity of selected High-Sierra meadow community types. Environ. Manage. 13:485-491. 